\title{
Pengaruh Pendidikan Kesehatan dengan Media Video Terhadap Pengetahuan Remaja Tentang Seks Pranikah di SMA Al-Mas'udiyyah Bandungan Kabupaten Semarang Tahun 2019
}

\author{
Putri Rahimah Mughny ${ }^{1}$, Heni Setyowati ${ }^{2}$, Eti Salafas ${ }^{3}$ \\ Program Studi D IV Kebidanan Fakultas Ilmu Kesehatan \\ Universitas Ngudi Waluyo Ungaran \\ Email : putrirahimah@gmail.com
}

\begin{abstract}
ABSTRAK
Hasil Survei Demografi dan Kesehatan Indonesia (SDKI) 2017 mengungkap sekitar 2\% remaja wanita usia 15-24 tahun dan 8\% remaja pria di rentang usia yang sama, telah melakukan hubungan seksual sebelum menikah. Remaja di Jawa Tengah mendapatkan penyuluhan kesehatan reproduksi dan seks pranikah hanya $31,4 \%$. Sehingga diberikan pendidikan kesehatan dengan media video tentang seks pranikah. Untuk menganalisa pengaruh pendidikan kesehatan dengan media video terhadap pengetahuan remaja tentang seks pranikah di SMA AlMas'udiyyah Kecamatan Bandungan Kabupaten Semarang Tahun 2019. Desain yang digunakan adalah quasi experimental pre and post test design tanpa kelompok kontrol. Populasi dalam penelitian ini yaitu seluruh siswa - siswi kelas X SMA Al-Mas'udiyyah yang berjumlah 103 siswa dengan jumlah sampel 24 responden. Analisis data menggunakan uji Wilcoxon dengan pengolahan data SPSS versi 16. Sebelum diberikan pendidikan kesehatan pengetahuan remaja dalam kategori cukup sebanyak 21 responden $(87,5 \%)$, setelah diberikan pendidikan kesehatan pengetahuan remaja dalam kategori baik meningkat menjadi 24 responden $(100 \%)$. Ada pengaruh antara pemberian pendidikan kesehatan dengan media video terhadap pengetahuan remaja tentang seks pranikah. Ada pengaruh antara pemberian pendidikan kesehatan dengan media video terhadap pengetahuan remaja tentang seks pranikah di SMA Al- Mas'udiyyah Kecamatan Bandungan Kabupaten Semarang. Diharapkan sekolah dapat memberikan pendidikan kesehatan dengan media video sehingga tidak membuat siswa bosan dan dapat lebih aktif dalam pembelajaran
\end{abstract}

\section{Kata kunci : Remaja, Pendidikan Kesehatan, Video, Pengetahuan, Seks Pranikah}

\begin{abstract}
The Influence of Health Education with Video Media on Adolescent Knowledge About Premarital Sex at SMA Al-Mas'udiyyah Bandungan Semarang Regency in 2019

The results of the 2017 Indonesian Demographic and Health Survey (SDKI) revealed that around 2\% of young women aged 15-24 and 8\% of young men in the same age range had sexual relations before marriage. Teenagers in Central Java who have received reproductive health and premarital sex education are only $31.4 \%$. So health education is provided with video on teenager knowledge about
\end{abstract}


premarital sex. To analyze the effect of health education with video toward teenagers knowledge about premarital sex at Al-Mas'udiyyah Senior High School in Bandungan, Semarang district 2019. The study design used was quasi experimental pre and post test design without a control group. The population was the whole of grade X students 103 students. 24 students were taken as the sample of this research. Data were analyzed using Wilcoxon test by SPSS data version 16. Before being given the knowledge health education of teenagers in sufficient categories as many as 21 respondents (87.5\%), after being given teenagers knowledge health education in the good category increased to 24 respondents (100\%). There is effect between the provision of health education with video on teenager knowledge about premarital sex. There is an influence between the provision of health education with video on teenager knowledge about premarital sex at Al-Mas'udiyyah Senior High School in Bandungan, Semarang District. It is hoped that schools can provide health education with video so that they do not make students bored and can be more active in learning.

\section{Keywords : Teenager, Health Education, Video, Knowledge, Premarital Sex}

\section{PENDAHULUAN}

Hasil Survei Demografi dan Kesehatan Indonesia (SDKI) 2017 mengungkap sekitar $2 \%$ remaja wanita usia 15-24 tahun dan 8\% remaja pria di rentang usia yang sama, telah melakukan hubungan seksual sebelum menikah. Sebanyak $11 \%$ di antaranya mengaku mengalami kehamilan tidak diinginkan.

Biro Pusat Statistik Jawa Tengah (2018) menyebutkan angka pernikahan dini Kabupaten Semarang sangat tinggi, sepanjang tahun 2015 tercatat telah terjadi 216 pernikahan yang direkomendasikan pengadilan. Data dari Dinas Kesehatan menunjukkan bahwa pengidap Human Immunodeficiency Virus (HIV), sebanyak 80 orang, Acquired Immune Deficiency Syndrome (AIDS) sebanyak 26 orang, dengan angka kematian 28 orang didominasi oleh kelompok usia muda.

Selain itu, dari hasil penelitian Pusat Informasi \& Layanan Remaja - Perkumpulan Keluarga Berencana Indonesia
(PILAR - PKBI) pada tahun 2015 kepada 2.845 responden pelajar di Kota dan Kabupaten Semarang menunjukkan bahwa 40 persen atau 1.125 remaja mengaku sudah pernah berpacaran dan 73.3 persen di antaranya mulai berpacaran dari umur 10 sampai 15 tahun. Di antara remaja yang pernah pacaran $11,2 \%$ atau 317 diantaranya mengaku sudah pernah memegang organ reproduksi pasangannya. Dari jumlah tersebut, $2,4 \%$ atau 71 remaja pernah melakukan petting dan 2,2\% atau 62 remaja pernah melakukan intercourse. Remaja di Jawa Tengah yang telah mendapatkan penyuluhan kesehatan reproduksi dan seks pranikah hanya $31,4 \%$.

Penggunaan melalui media audio visual seperti video merupakan salah satu teknik pengajaran yang mempunyai banyak keunggulan dilihat dari sasaran program maupun situasi dan kondisi siswa. Dilihat dari sasaran program, siswa SMA merupakan masa yang belum mampu memahami informasi secara baik karena pola fikir yang belum matang, sehingga pengajaran dengan media 
video dapat membantu siswa memahami materi yang diberikan. Kemudahan penerimaan informasi dapat mempermudah peningkatan pengetahuan siswa terhadap kesehatan reproduksi (Amalia, 2012).

Berdasarkan hasil wawancara Pada 10 siswa dengan mewawancarai 5 remaja putri dan 5 remaja putra di dapatkan hasil 9 remaja pernah berpacaran, 6 diantaranya sedang memiliki pacar. Responden diberikan pertanyaan tentang seks pranikah. $50 \%$ remaja tidak tahu pengertian seks pranikah, $60 \%$ remaja tidak tahu jenis-jenis perilaku seks pranikah, $50 \%$ remaja tidak tahu penyebab perilaku seks pranikah, $40 \%$ tidak tahu dampak dari seks pranikah, 50\% tidak tahu penyakit yang dapat terjadi akibat seks pranikah, 60\% remaja tidak tahu cara penularan Penyakit Menular Seksual (PMS) dan HIV/AIDS dan 50\% remaja tidak tahu cara pencegahan dari PMS dan HIV/AIDS. $50 \%$ remaja mengaku belum pernah mendapatkan informasi tentang seks pranikah, $30 \%$ mendapatkan informasi dari internet dan 20\% mendapatkan informasi dari guru.

\section{TUJUAN PENELITIAN}

Tujuan Umum

Menganalisa pengaruh pendidikan kesehatan dengan media video terhadap pengetahuan remaja tentang seks pranikah di SMA AlMas'udiyyah Bandungan Kabupaten Semarang Tahun 2019.

Tujuan Khusus

1. Mengetahui gambaran pengetahuan remaja tentang seks pranikah sebelum diberikan pendidikan kesehatan dengan media video.
2. Mengetahui gambaran pengetahuan remaja tentang seks pranikah setelah diberikan pendidikan kesehatan dengan media video.

3. Menganalisa pengaruh pendidikan kesehatan dengan media video terhadap pengetahuan remaja tentang seks pranikah.

\section{MANFAAT PENELITIAN}

1. Bagi tempat penelitian

Menjadi bahan masukan untuk mengetahui sejauh mana pengetahuan murid SMA AlMas'udiyyah Bandungan Kabupaten Semarang tentang seks pranikah dan menjadi acuan dalam pencegahan dan mengatasi masalah remaja

2. Bagi Institusi Pendidikan

Sebagai tambahan bahan referensi kepustakaan mengenai pengaruh pendidikan kesehatan dengan media video terhadap pengetahuan remaja tentang seks pranikah

3. Bagi peneliti selanjutnya.

Bahan perbandingan bagi peneliti selanjutnya serta diharapkan dapat memberikan kontribusi pada bidang kesehatan yang berkaitan dengan pengetahuan remaha tentang seks pranikah

\section{METODE}

Desain yang digunakan adalah quasi experimental pre dan post test design dengan rancangan pre dan post tanpa kelompok kontrol atau pre dan post test without control. Penelitian ini dilakukan di SMA Al-Mas'udiyyah Bandungan Kabupaten Semarang pada 24 Mei 2019.

Populasi dalam penelitian ini adalah siswa kelas $\mathrm{X} \quad \mathrm{Al}-$ Mas'udiyyah Kecamatan Bandungan 
Kabupaten Semarang yang berjumlah 103 siswa. Sampel dalam penelitian ini sebanyak 24 responden. Teknik pengambilan sampel untuk penelitian ini menggunakan Proportional Random Sampling kemudian dilakukan teknik Simple Random Sampling yaitu pengambilan sampel secara acak sederhana. Teknis analisis data yang digunakan adalah uji Wilcoxon.
Prosedur pengambilan data primer, dengan cara membagikan kuesioner ke responden.

\section{HASIL DAN PEMBAHASAN}

\section{Analisis Univariat}

1. Pengetahuan Remaja Tentang Seks Pranikah Sebelum Diberikan Pendidikan Kesehatan Dengan Media Video

Tabel 1 Distribusi Frekuensi Berdasarkan Pengetahuan Remaja Tentang Seks Pranikah Sebelum Diberikan Pendidikan Kesehatan Dengan Media video di SMA Al-Mas'udiyyah Bandungan Kabupaten Semarang Tahun 2019

\begin{tabular}{lcc}
\hline Pengetahuan & Frekuensi & Presentasi (\%) \\
\hline Kurang & 2 & $8,4 \%$ \\
Cukup & 21 & $87,5 \%$ \\
Baik & 1 & $4,1 \%$ \\
\hline Jumlah & 24 & $100 \%$ \\
\hline
\end{tabular}

Berdasarkan tabel 1 diatas dapat dikatakan bahwa sebelum diberikan pendidikan kesehatan dengan media video di SMA AlMas'udiyyah Kecamatan Bandungan Kabupaten Semarang, sebagian besar dalam kategori cukup yaitu sejumlah 21 responden $(87,5 \%)$, kategori rendah sejumlah 2 responden $(8,4 \%)$ dan kategori baik sejumlah 1 responden $(4,1 \%)$.

Hasil penelitian menunjukkan bahwa pengetahuan remaja tentang seks pranikah sebelum diberikan pendidikan kesehatan dengan media video di SMA AlMas'udiyyah pada tabel 4.1 dalam kategori cukup sebanyak 21 responden $(87,5 \%)$, kategori pengetahuan kurang sebanyak 2 responden $(8,4 \%)$, kategori baik sebanyak 1 responden $(4,1 \%)$.

Tingginya kategori pengetahuan cukup disebabkan berbagai macam faktor. Salah satunya faktor informasi.
Meskipun banyak cara mendapatkan informasi tentang sex education di media massa, namun tidak semua sumber dapat memberikan informasi yang benar tentang pengertian dan bentuk-bentuk dari seks pranikah. menurut Astutik (2013) dan Triyani (2012) adapun beberapa faktor yang mempengaruhi pengetahuan seseorang adalah usia, pendidikan, pengalaman, informasi, sosial budaya ekonomi, lingkungan.

Masih banyaknya
responden dengan kategori pengetahuan cukup sebanyak 21 responden $(87,5 \%)$ bisa dilihat dari jumlah responden yang menjawab soal masih kurang tepat terutama dalam pengertian perilaku seksual, bentuk perilaku seks pranikah. Responden belum sepenuhnya mengerti pengertian dari perilaku seksual dan belum mengetahui bentuk - bentuk dari seksual pranikah. 
Indikator pernyataan tentang pengertian dari perilaku seks pranikah yang ditunjukkan dalam soal nomor 1 dengan soal "Perilaku seksual pranikah adalah perilaku yang melibatkan sentuhan secara fisik anggota badan antara pria dan wanita yang telah mencapai pada tahap hubungan intim, biasanya dilakukan oleh pasangan suami istri" yaitu sejumlah $17(70,8 \%)$ responden menjawab salah dan soal nomor 2 dengan soal "Perilaku seksual adalah perilaku yang bertujuan untuk menarik perhatian lawan jenis" sejumlah $14(58,3 \%)$ responden menjawab salah. Menurut Hanifa (dalam penelitian "Hubungan Antara Pengetahuan Kesehatan Reproduksi Dan Sikap Seksualitas Dengan Perilaku Pacaran Pada Pelajar SLTA Di Kota Semarang" oleh Guruh, 2015), orientasi berpacaran kaum remaja telah berubah. Dulu tujuan dari pacaran untuk mencari calon pasangan hidup (suami istri), namun saat ini tujuan dari pacaran untuk gengsi, fantasi, bahkan eksploitasi seks. Berpacaran bagi remaja yang tumbuh dalam dunia modern seperti sekarang ini dianggap wajar-wajar saja. Pacaran dalam artian mengenal lawan jenis mungkin masih dapat ditoleransi.

Indikator pernyataan tentang bentuk perilaku seksual pada soal nomor 6 dengan soal "Berpegangan tangan adalah bukan perilaku seksual" sejumlah $22(91,6 \%)$ menjawab salah. Menurut Sarwono (2016), bentuk perilaku seks pranikah yang dilakukan remaja antara lain adalah masturbasi atau onani, berpegangan tangan, berpelukan, berciuman, meraba bagian tubuh, petting, dan melakukan hubungan seksual. Hasil penelitian terdahulu yaitu penelitian yang dilakukan Evidanika, dkk (2009) dengan judul "Hubungan Antara Pengetahuan Seksualitas Dan Kualitas Komunikasi Orang Tua Dan Anak Dengan Perilaku Seks Bebas Pada Remaja Siswa-Siswi MAN Gondarejo Karanganyar" mengungkapkan sejumlah 52,2\% siswa-siswi MAN Gondangrejo Kranganyar menyatakan bahwa berpegangan tangan dengan lawan jenis itu adalah hal yang wajar. Berpegangan tangan tidak menimbulkan rangsangan seksual yang kuat namun biasanya muncul keinginan untuk mencoba aktivitas seksual yang lain. Pengetahuan remaja juga masih kurang tentang bentuk perilaku seksual dapat dilihat dalam soal nomor 8 dengan soal "Berfantasi adalah perilaku membayangkan dan mengimajinasikan aktivitas seksual yang bertujuan untuk menimbulkan perasaan erotisme. Jika dibiarkan terlalu lama, maka kegiatan produktif teralif kepada kegiatan memanjakan diri dan itu bukan termasuk seksual pranikah remaja" sejumlah 20 (83,3\%) responden menjawab salah. Hasil penelitian yang dilakukan oleh Pratiwi (2015) dengan judul "Hubungan Religiusitas Dengan Perilaku Seksual Pada Remaja Di Sma Negeri 1 Banguntapan Bantul Yogyakarta" menunjukkan pada perilaku seksual yang berupa fantasi seksual, dihasilkan $28 \%$ remaja kadang-kadang membayangkan atau berkeinginan untuk 
melakukannya saat membaca cerita dewasa/cerita porno. Ini sesuai dengan teori menurut Dariyo (Dalam penelitian "Hubungan Religiusitas Dengan Perilaku Seksual Pada Remaja Di Sma Negeri 1 Banguntapan Bantul Yogyakarta" oleh Pratiwi, 2015) bahwa kegiatan berfantasi seksual ini bertujuan menambah kesenangan pada aktivitas seksual yang dilakukan, subtitusi untuk pengalaman nyata yang tidak mungkin dilakukan. Kegiatan ini dapat membuat remaja ingin mencoba-coba dan membuat rasa penasaran remaja tinggi.

Pengetahuan remaja
yang kurang tentang seks pranikah dapat ditingkatkan dengan berbagai macam cara salah satunya dengan memberikan pendidikan kesehatan. Menurut Astutik (2013) dan Triyani (2012), jika seseorang memiliki tingkat pendidikan yang rendah, bisa mendapatkan informasi yang baik dari berbagai media seperti televisi, radio, surat kabar, majalah, dan lain-lain. Hal tersebut dapat meningkatkan pengetahuan seseorang.

2. Pengetahuan Remaja Tentang Seks Pranikah Sesudah Diberikan Pendidikan Kesehatan Dengan Media Video

Tabel 2 Distribusi Frekuensi Berdasarkan Pengetahuan Remaja Tentang Seks Pranikah Sesudah Diberikan Pendidikan Kesehatan Dengan Media video di Al-Mas'udiyyah Bandungan Kabupaten Semarang Tahun 2019

\begin{tabular}{lcc}
\hline Pengetahuan & Frekuensi & Presentasi (\%) \\
\hline Kurang & 0 & $0 \%$ \\
Cukup & 0 & $0 \%$ \\
Baik & 24 & $100 \%$ \\
\hline Jumlah & 24 & $100 \%$ \\
\hline
\end{tabular}

Berdasarkan tabel 2 dapat dikatakan bahwa sesudah diberikan pendidikan kesehatan dengan media video di SMA AlMas'udiyyah Kecamatan Bandungan Kabupaten Semarang, seluruhnya dalam kategori baik yaitu sejumlah 24 responden (100\%).

Hasil penelitian menunjukkan bahwa pengetahuan remaja tentang seks pranikah sesudah diberikan pendidikan kesehatan dengan media video di SMA AlMas'udiyyah dalam kategori baik sebanyak 24 responden (100\%), kategori pengetahuan kurang sebanyak 0 responden $(0 \%)$, kategori cukup sebanyak 0 responden $(0 \%)$.

Menurut Sumiati (2009) menyatakan pendidikan seks dapat memberikan pengetahuan tentang kesalahan dan penyimpangan seksual agar individu dapat menjaga diri dan melawan eksploitasi yang dapat mengganggu kesehatan fisik dan mental dan dapat membentuk sikap serta memberikan pengertian terhadap seks dalam semua manifestasi yang bervariasi.

Meningkatnya

pengetahuan responden dengan kategori baik sebanyak 24 
responden $(100 \%)$ dapat dilihat dari jumlah responden menjawab soal dengan tepat. Indikator pernyataan pengertian dari perilaku seks pranikah yang ditunjukkan dalam soal nomor 1 yaitu $8 \quad(33,3 \%)$ responden menjawab benar, soal nomor 2 yaitu $23 \quad(95,8 \%)$ responden menjawab benar. Indikator pernyataan tentang faktor penyebab remaja melakukan seks pranikah pada soal nomor 3, 4, 5 sejumlah $24(100 \%)$ responden menjawab benar, indikator pernyataan tentang bentuk perilaku seksual pada soal nomor 6 sejumlah $21(87,5 \%)$ responden menjawab benar, soal nomor 7 sejumlah $24(100 \%)$ responden menjawab benar, soal nomor 8 sejumlah $7(29,1 \%)$ responden menjawab benar. Indikator pernyataan tentang alasan remaja melakukan seks pranikah pada soal nomor 9, 10 sejumlah 24 $(100 \%)$ responden menjawab benar, indikator pernyataan resiko perilaku seks pranikah pada soal 11, 12, 13 sejumlah 24 $(100 \%)$ responden menjawab benar, indikator pernyataan tentang cara menghindari seks pranikah pada soal 14, 15 sejumlah $24(100 \%)$ responden menjawab benar.

Menurut Triwibowo dan Puspahandani (2015), pendidikan kesehatan adalah proses untuk mengubah perilaku manusia yang meliputi pengetahuan, sikap, atau perbuatan yang berhubungan dengan tujuan hidup sehat baik secara individu atau pun kelompok serta menggunakan fasilitas pelayanan kesehatan dengan tepat dan sesuai.
Pendidikan kesehatan dengan media video memberikan rasangan melalui mata dan telinga menurut Maulana (2009) bahwa panca indera yang paling banyak menyalurkan pengetahuan ke otak adalah mata (sekitar $75 \%$ sampai $87 \%$ ), sedangkan $13 \%$ sampai $25 \%$ pengetahuan manusia diperoleh dan disalurkan melalui panca indera yang lain. Semakin banyak indera yang dirangsang maka informasi yang masuk semakin mudah. Menurut Notoatmodjo (2009), informasi akan tersimpan sebanyak 20\% jika disampaikan melalui media visual, $50 \%$ bila disampaikan melalui media video dan $70 \%$ bila dilaksakanan dalam praktek nyata.

Penelitian ini di perkuat oleh penelitian Sari (2012) menunjukan adanya pengaruh pendidikan seks terhadap pengetahuan remaja tentang seks pranikah di SMA Negeri Rongkop Kidul tahun 2012 dengan hasil pengetahuan tentang seks pranikah sebelum pendidikan seks terbanyak pada tingkat pendidikan cukup 56 orang $(54 \%)$, meningkat setelah pendidikan seks dengan hasil terbanyak pada tingkat pengetahuan tinggi 57 orang $(55,9 \%)$. Hal ini menunjukan bahawa dengan adanya penyuluhan kesehatan tentang bahya seks pranikah dapat neningkatkan pengetahuan remaja, dengan pengetahuan yang baik maka akan berpengaruh terhadap sikap remaja

3. Jawaban Kusioner Responden Sebelum Dan Sesudah Diberikan 
Pendidikan Kesehatan Dengan Media Video

Tabel 3 Distribusi Jawaban Pengetahuan Remaja Sebelum Dan Sesudah Diberikan Pendidikan Kesehatan Tentang Seks Pranikah Dengan Media Video

\begin{tabular}{|c|c|c|c|c|c|}
\hline \multirow{2}{*}{ No } & \multirow{2}{*}{ Pernyataan } & \multicolumn{2}{|c|}{ Pre-test } & \multicolumn{2}{|c|}{ Post-test } \\
\hline & & Benar & Salah & Benar & Salah \\
\hline 1. & $\begin{array}{l}\text { Perilaku seksual pranikah adalah } \\
\text { perilaku yang melibatkan sentuhan } \\
\text { secara fisik anggota badan antara } \\
\text { pria dan wanita yang telah } \\
\text { mencapai pada tahap hubungan } \\
\text { intim, biasanya dilakukan oleh } \\
\text { pasangan suami istri }\end{array}$ & $\begin{array}{c}7 \\
(29,1 \%)\end{array}$ & $\begin{array}{c}17 \\
(70,8 \%)\end{array}$ & $\begin{array}{c}8 \\
(33,3 \%)\end{array}$ & $\begin{array}{c}16 \\
(66,6 \%)\end{array}$ \\
\hline 2. & $\begin{array}{l}\text { Perilaku seksual adalah perilaku } \\
\text { yang bertujuan untuk menarik } \\
\text { perhatian lawan jenis }\end{array}$ & $\begin{array}{c}10 \\
(41,1 \%)\end{array}$ & $\begin{array}{c}14 \\
(58,3 \%)\end{array}$ & $\begin{array}{c}23 \\
(95,8 \%)\end{array}$ & $\begin{array}{c}1 \\
(4,1 \%)\end{array}$ \\
\hline 3. & $\begin{array}{l}\text { Penyebab remaja melakukan } \\
\text { seksual pranikah adalah adanya } \\
\text { dorongan hasrat atau nafsu dari diri } \\
\text { sendiri, adanya keingintahuan dan } \\
\text { coba - coba }\end{array}$ & $\begin{array}{c}23 \\
(95,8 \%)\end{array}$ & $\begin{array}{c}1 \\
(4,1 \%)\end{array}$ & $\begin{array}{c}24 \\
(100 \%)\end{array}$ & $\begin{array}{c}0 \\
(0 \%)\end{array}$ \\
\hline 4. & $\begin{array}{l}\text { Faktor yang mempengaruhi remaja } \\
\text { terjerumus dalam seksual pranikah } \\
\text { adalah komunikasi yang kurang dan } \\
\text { keluarga }\end{array}$ & $\begin{array}{c}22 \\
(91,6 \%)\end{array}$ & $\begin{array}{c}2 \\
(8,3 \%)\end{array}$ & $\begin{array}{c}24 \\
(100 \%)\end{array}$ & $\begin{array}{c}0 \\
(0 \%)\end{array}$ \\
\hline 5. & $\begin{array}{l}\text { Faktor yang mempengaruhi remaja } \\
\text { terjerumus dalam seksual pranikah } \\
\text { adalah pengaruh teman sebaya }\end{array}$ & $\begin{array}{c}23 \\
(95,8 \%)\end{array}$ & $\begin{array}{c}1 \\
(4,1 \%)\end{array}$ & $\begin{array}{c}24 \\
(100 \%)\end{array}$ & $\begin{array}{c}0 \\
(0 \%)\end{array}$ \\
\hline 6. & $\begin{array}{l}\text { Berpegangan tangan adalah bukan } \\
\text { perilaku seksual }\end{array}$ & $\begin{array}{c}2 \\
(8,3 \%) \\
\end{array}$ & $\begin{array}{c}22 \\
(91,6 \%) \\
\end{array}$ & $\begin{array}{c}21 \\
(87,5 \%)\end{array}$ & $\begin{array}{c}3 \\
(12,5 \%) \\
\end{array}$ \\
\hline 7. & $\begin{array}{l}\text { Berciuman adalah salah satu bentuk } \\
\text { perilaku seksual }\end{array}$ & $\begin{array}{c}20 \\
(83,3 \%) \\
\end{array}$ & $\begin{array}{c}4 \\
(16,6 \%) \\
\end{array}$ & $\begin{array}{c}24 \\
(100 \%) \\
\end{array}$ & $\begin{array}{c}0 \\
(0 \%) \\
\end{array}$ \\
\hline 8. & $\begin{array}{l}\text { Berfantasi adalah perilaku } \\
\text { membayangkan dan } \\
\text { mengimajinasikan aktivitas seksual } \\
\text { yang bertujuan untuk menimbulkan } \\
\text { perasaan erotisme. Jika dibiarkan } \\
\text { terlalu lama, maka kegiatan } \\
\text { produktif teralif kepada kegiatan } \\
\text { memanjakan diri dan itu bukan } \\
\text { termasuk seksual pranikah remaja }\end{array}$ & $\begin{array}{c}4 \\
(16,6 \%)\end{array}$ & $\begin{array}{c}20 \\
(83,3 \%)\end{array}$ & $\begin{array}{c}7 \\
(29,1 \%)\end{array}$ & $\begin{array}{c}17 \\
(70,8 \%)\end{array}$ \\
\hline 9. & $\begin{array}{l}\text { Perubahan biologis yang terjadi } \\
\text { pada masa remaja pubertas dan } \\
\text { pengaktifan hormonal dapat } \\
\text { menimbulkan perilaku seksual }\end{array}$ & $\begin{array}{c}18 \\
(75 \%)\end{array}$ & $\begin{array}{c}6 \\
(25 \%)\end{array}$ & $\begin{array}{c}24 \\
(100 \%)\end{array}$ & $\begin{array}{c}0 \\
(0 \%)\end{array}$ \\
\hline 10. & $\begin{array}{l}\text { Adanya tekanan dari pacar dan } \\
\text { teman sebaya dapat menjadi alasan } \\
\text { remaja untuk berprilaku seksual } \\
\text { pranikah }\end{array}$ & $\begin{array}{c}12 \\
(50 \%)\end{array}$ & $\begin{array}{c}12 \\
(50 \%)\end{array}$ & $\begin{array}{c}24 \\
(100 \%)\end{array}$ & $\begin{array}{c}0 \\
(0 \%)\end{array}$ \\
\hline 11. & $\begin{array}{l}\text { Resiko terjadinya seksual pranikah } \\
\text { adalah hamil diluar nikah }\end{array}$ & $\begin{array}{c}23 \\
(95,8 \%)\end{array}$ & $\begin{array}{c}1 \\
(4,1 \%)\end{array}$ & $\begin{array}{c}24 \\
(100 \%)\end{array}$ & $\begin{array}{c}0 \\
(0 \%)\end{array}$ \\
\hline 12. & Hubungan seksual pranikah dapat & 21 & 3 & 24 & 0 \\
\hline
\end{tabular}




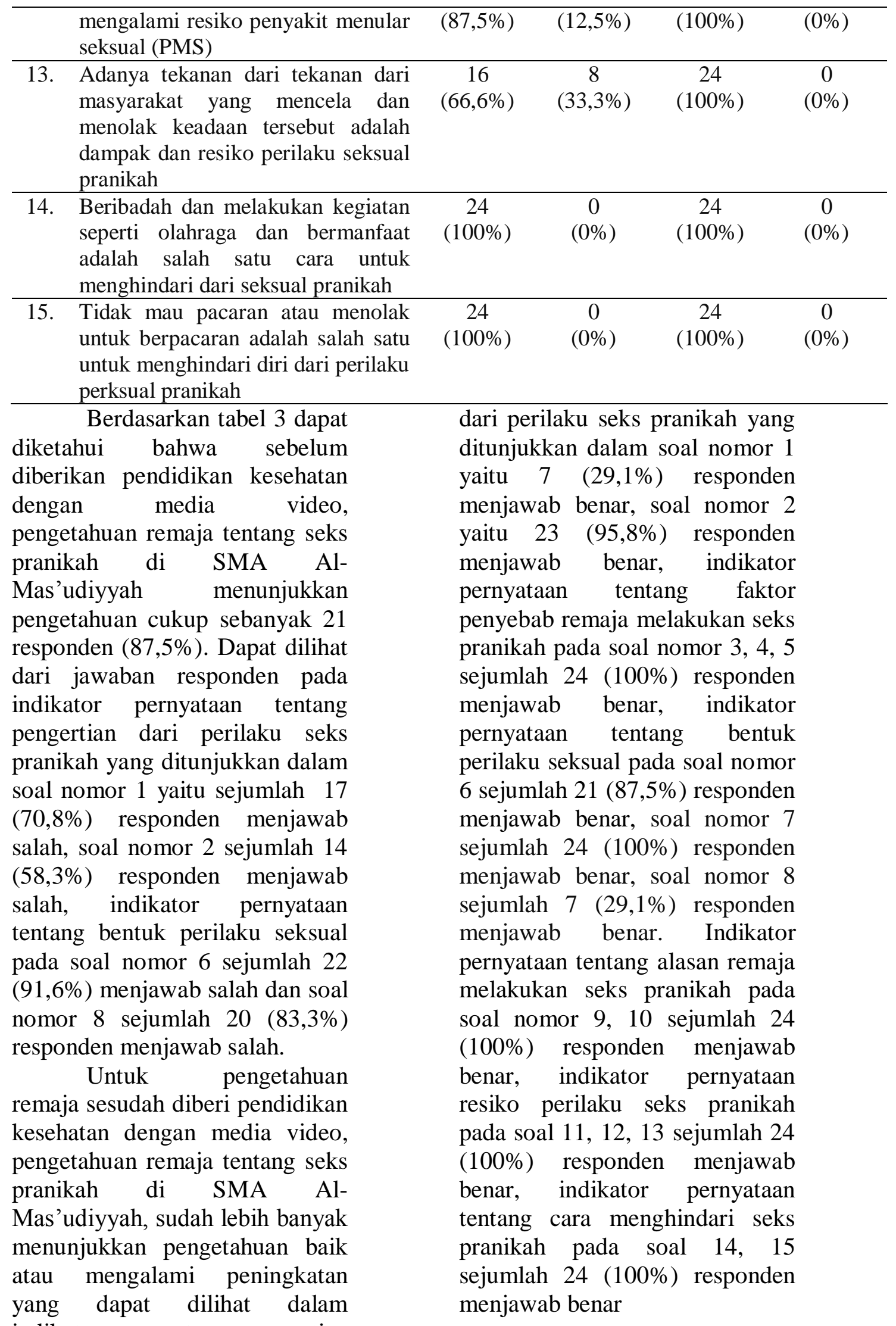

\section{Analisis Bivariat}


Tabel 4 Perbedaan Pengetahuan Remaja Tentang Seks Pranikah Sebelum Dan Sesudah Diberikan Pendidikan Kesehatan Dengan Media video

\begin{tabular}{cccccc}
\hline Variabel & Intervensi & N & Mean & Z & p-value \\
& & & & & \\
\hline Pengetahuan & Pre-test & 24 & 12.50 & -4.318 & 0,000 \\
& Post-test & & & & \\
\hline Berdasarkan & tabel 4. uji & & meningkatkan & & pengetahuan
\end{tabular}

Wilcoxon, pengetahuan didapatkan $p$ value sebesar 0,000 . Terlihat bahwa $p$-value $<\alpha(0,05)$. Ini menunjukkan bahwa ada pengaruh yang signifikan tingkat pengetahuan remaja tentang seks pranikah sebelum dan sesudah diberikan pendidikan kesehatan dengan media video di SMA AlMas'udiyyah Kecamatan Bandungan Kabupaten Semarang.

Berdasarkan hasil penelitian, diketahui bahwa pengetahuan remaja tentang seks pranikah sebelum diberikan pendidikan kesehatan dengan media video sebagian besar dalam kategori cukup yaitu sejumlah 21 responden $(87,5 \%)$, kategori rendah sejumlah 2 responden $(8,4 \%)$ dan kategori baik sejumlah 1 responden $(4,1 \%)$ meningkat menjadi kategori baik sebanyak 24 responden (100\%), kategori cukup sebanyak 0 responden (0\%), kategori kurang sebanyak 0 responden $(0 \%)$.

Menurut Astutik (2013) dan Triyani (2012) adapun beberapa faktor yang mempengaruhi pengetahuan seseorang adalah usia, pendidikan, pengalaman, informasi, sosial budaya ekonomi, lingkungan. Pengetahuan remaja yang kurang tentang seks pranikah dapat ditingkatkan dengan berbagai macam cara salah satunya dengan memberikan pendidikan kesehatan, jika seseorang memiliki tingkat pendidikan yang rendah, bisa mendapatkan informasi yang baik dari berbagai media seperti televisi, radio, surat kabar, majalah, dan lainlain. Hal tersebut dapat seseorang.

Berdasarkan uji Wilcoxon, didapatkan nilai $\mathrm{Z}-4.318$ dengan $p$ value sebesar 0,000 . Oleh karena $p$ value $(0,000)<\alpha(0,05)$, ini menunjukkan bahwa ada perbedaan signifikan pengetahuan remaja tentang seks pranikah sebelum dan sesudah diberikan pendidikan kesehatan dengan media video.

Menurut Arif (2013) dalam penelitian "Pengaruh media video terhadap pengetahuan dalam pencegahan perilaku sesks pranikah siswa SMP" oleh Lia, dkk (2017) menunjukan bahwa pengetahuan dapat dipengaruhi oleh pemberian media video karena video dapat mencerminkan adanya penyerapan informasi yang lebih efektif dengan menggunakan indera penglihatan dan pendengaran serta dapat meningkatkan pengetahuan dibandingkan hanya menggunakan indera penglihatan.

Pendidikan kesehatan dengan media video memberikan rasangan melalui mata dan telinga menurut Maulana (2009) bahwa panca indera yang paling banyak menyalurkan pengetahuan ke otak adalah mata (sekitar $\quad 75 \%$ sampai $87 \%$ ), sedangkan $13 \%$ sampai $25 \%$ pengetahuan manusia diperoleh dan disalurkan melalui panca indera yang lain. Semakin banyak indera yang dirangsang maka informasi yang masuk semakin mudah.

Menurut April W Amstrong, etc (2011). Dalam jurnal penelitian dengan judul "Effects of video-based, online education on behavioral and 
knowledge outcomes in sunscreen use: A randomized controlled trial" juga mengungkapkan peningkatan signifikan yang lebih besar dalam skor pengetahuan dari anggota kelompok video dibandingkan dengan kelompok pamflet. Maka pembelajaran berbasis dengan video adalah media pendidikan yang lebih efektif untuk mengajarkan pengetahuan perlindungan matahari dan mendorong penggunaan tabir surya daripada menggunakan pamflet.

\section{KESIMPULAN DAN SARAN Kesimpulan}

1. Pengetahuan remaja tentang seks pranikah sebelum diberikan pendidikan kesehatan dengan media video sebagian besar dalam kategori cukup yaitu sejumlah 21 responden $(87,5 \%)$, kategori rendah sejumlah 2 responden $(8,4 \%)$ dan kategori baik sejumlah 1 responden $(4,1 \%)$

2. Pengetahuan remaja tentang seks pranikah setelah diberikan pendidikan kesehatan dengan media video meningkat menjadi kategori baik sebanyak 24 responden (100\%), kategori cukup sebanyak 0 responden $(0 \%)$, kategori kurang sebanyak 0 responden $(0 \%)$,

3. Ada pengaruh antara pemberian pendidikan kesehatan dengan media video terhadap pengetahuan remaja tentang seks pranikah. ( $P$-value sebesar 0,000).

\section{Saran}

1. Bagi Tempat Penelitian

Diharapkan sekolah mengevaluasi dan meningkatkan pengetahuan remaja tentang seks dengan memberikan pendidikan kesehatan menggunakan metode yang bervariasi seperti dengan media video.

2. Bagi Tenaga Kesehatan

Diharapkan meningkatkan

pengembangan pelayanan

kesehatan khususnya layanan kesehatan pada remaja.

3. Bagi peneliti selanjutnya

Diharapkan dapat mengembangkan penelitian ini dengan cara meneliti variabel yang belum diteliti seperti metode yang lebih bervariasi dan faktor apa saja yang bisa mempengaruhi pengetahuan remaja tentang seks pranikah.

\section{DAFTAR PUSTAKA}

Amalia, S. (2012). Pengembangan Multimedia Pembelajaran Berbentuk Komik Untuk Menunjang Kegiatan Pembelajaran. Skripsi. UPI Bandung.

April W Amstrong, etc (2011). Effects of video-based, online education on behavioral and knowledge outcomes in sunscreen use: A randomized controlled trial. Journal of Heallth, vol. 83, no. 2, hh. 273277.

Astutik, P. 2013. Pengetahuan, Sikap Ibu Rumah Tangga Mengenai Infeksi Menular Seksual Termasuk HIV/AIDS Serta Perilaku Pencegahannya di Kelurahan Sanur, Kecamatan Denpasar Selatan, Kota Denpasar Tahun 2013. Community Health. Vol. 1. No. 3. Juli. 2013.

Badan Pusat Statistik Propinsi Jawa Tengah, 2018. Jawa Tengah Dalam Angka Tahun 2018. Semarang : Badan Pusat Statistik. 
Lia Kurniasari, dkk (2017) Pengaruh Media Video Terhadap Pengetahuan Dalam Pencegahan Perilaku Seks Pranikah Siswa SMP. Jurnal Kesehatan Masyarakat

Maulana, H. 2009. Promosi kesehatan. Jakarta: EGC

Mertia, Evidanika Nifa, dkk. 2009. Hubungan Antara Pengetahuan Seksualitas Dan Kualitas Komunikasi Orang Tua Dan Anak Dengan Perilaku Seks Bebas Pada Remaja Siswa-Siswi MAN Gondarejo Karanganyar. Jurnal Psikologi volume 3.

Notoatmodjo, S. 2009. Promosi Kesehatan dan Ilmu Perilaku. Jakarta : Rineka Cipta

PILAR PKBI Jateng. 2015 (a). Remaja Butuh Akses Layanan Kesehatan Reproduksi Yang Ramah. Semarang: Divisi Layanan PILAR

Prayoga, Guruh. 2015. Hubungan Antara Pengetahuan Kesehatan
Reproduksi Dan Sikap

Seksualitas Dengan Perilaku Pacaran Pada Pelajar SLTA Di Kota Semarang. Skripsi. Universitas Muhammadiyah Surakarta.

Sarwono, S.W 2016. Psikologi Remaja (Edisi Revisi). Jakarta: PT Raja Grafindo Persada.

SDKI. 2017. Survei Demografi Kesehatan Indonesia. Jakarta.

Sumiati, dkk. 2009. Kesehatan Jiwa Remaja \& Konseling. Jakarta: Trans Info Media.

Triwibowo, C., \& Puspahandani, E. M. 2015. Pengantar Dasar Ilmu Kesehatan Masyarakat. Jakarta : Nuha Medika

Utami, Pratiwi Jati. 2015. Hubungan Religiusitas dengan Perilaku Seksual pada Remaja di SMA Negeri 1 Banguntapan Bantul Yogyakarta Tahun 2015. Skripsi. STIKES Aisyiyah Yogyakarta 